\title{
PENGOLAHAN LIMBAH BATANG SAWIT MENJADI PUPUK KOMPOS DENGAN MENGGUNAKAN DEKOMPOSER MIKROORGANISME LOKAL (MOL) BONGGOL PISANG
}

\section{WASTETREATMENT OF PALM OIL TRUNKS INTO COMPOST BY USING BANANA STEM AS LOCAL MICROORGANISMS}

\author{
Nina Veronika*), Anna Dhora, dan Sri Wahyuni*) \\ Program Studi Teknik Pengolahan Sawit, Politeknik Kampar \\ Jl. Tengku Muhammad KM. 2, Bangkinang, Riau, Indonesia \\ Email :nnaveronika@gmail.com; yuni.tip@gmail.com \\ Makalah: Diterima 15 Oktober 2018; Diperbaiki 21 Juni 2019; Disetujui 7 Juli 2019
}

\begin{abstract}
One of the main problem in palm plantations during the rejuvenations is the utilization of palm oil waste especially the palm trunks that reaching $220 \mathrm{~m}^{3} /$ hectare. Based on that reason, we need a method of utilizing it that can increase the value from palm oil waste, not just for the benefits of oil palm farmers but also for the environment. Palm oil waste has the potential to become the raw material for making organic fertilizer (compost), it has a high nutrient content and can improve the quality of the fertilizer produced. The objective of this research was to produce a bio-fertilizer with a high quality based on the proper standards. This research was conducted in two stages including the produce of local microorganism (MOL) from banana stem and the composting stage. The composition of local microorganism materials was banana stem: cattle urine: coconut water: brown sugar with the raio of 2: 1: 1: 1. The composting stage was started after all materials were chopped and stirred together before it composted for one month by varying between the main materials and additional ingredients. The compositions of the palm trunks as the main ingredient were divided in five variations, i.e. 3, 6, 9, 12, and 15\% (w/w/), this variations were composted together with two types of additional ingredients of POME and goat manure. Based on the results of the compost analysis, the best composition was the variables of palm trunks: pome: rice husk: ash $=3: 10: 2: 1$ with the results of analysis were water content of $16.30 \%$, total NPK of $6.08 \%$, c-organic content of $44.10 \%$, the ratio $\mathrm{C} / \mathrm{N}$ of 16.30 and pH of 8.16 and it had been fitted with bio-fertilizer standard (Permentan No. 70/Permentan/SR. 140/10/2011).
\end{abstract}

Keywords: palm oil replantation, bio fertilizer, palm oil trunks, decomposer, local microorganism

\section{ABSTRAK}

Pemanfaatan limbah batang sawit sampai saat ini belum optimal dan masih menjadi permasalahan pada saat peremajaan perkebunan sawit karena jumlahnya yang sangat besar, yaitu mencapai $220 \mathrm{~m}^{3} /$ hektar. Untuk itu sangat diperlukan metode pemanfaatan limbah batang sawit menjadi produk yang bernilai jual, ramah lingkungan dan memberikan manfaat bagi petani sawit. Penelitian ini bertujuan untuk menghasilkan pupuk kompos yang berkualitas dan sesuai standar. Penelitian ini dilakukan dalam dua tahap, yaitu pembuatan Mikroorganisme Lokal (MOL) bonggol pisang dan tahap pengomposan. Pembuatan MOL dilakukan dengan menfermentasikan bonggol pisang dan bahan lainnyadengan komposisi yaitu bonggol pisang: urin sapi: air kelapa: gula merah dengan perbandingan 2:1:1:1\% (b/b). Tahap pengomposan dilakukan setelah seluruh bahan baku dicacah dan diaduk merata kemudian dikomposting selama satu bulan dengan memvariasikan antara bahan baku utama dan bahan tambahan. Komposisi batang sawit sebagai bahan utama dilakukan dalam lima variasi yaitu 3,6,9,12,15\% (b/b), yang dikomposting bersama bahan tambahan dalam dua variasi jenis yaitu POME dan kotoran kambing \% (b/b). Berdasarkan hasil analisis, maka pupuk kompos terbaik diperoleh pada perlakuan batang sawit dan POME dengan perbandingan komposisi yaitu 3:10:2:1 \%(b/b) dengan karakteristik, nilai kadar air 16,30\%, total NPK 6,08\%, kandungan C-organik 44,10\%, rasio $\mathrm{C} / \mathrm{N}=16,30$ dan $\mathrm{pH} 8,16$. Karakteristik pupuk kompos yang dihasilkan telah memenuhi standar Peraturan Menteri Pertanian No. 70/Permentan/SR. $140 / 10 / 2011$.

Kata kunci: peremajaan, limbah sawit, MOL bonggol pisang, kompos

\section{PENDAHULUAN}

Pesatnya perkembangan industri sawit di Indonesia diiringi dengan meningkatnya luas perkebunan sawit baik milik masyarakat maupun milik perusahaan perkebunan. Pada tahun 2014, Indonesia memiliki luas areal perkebunan sawit sebesar 11,4 juta Ha dengan produksi 30,95 juta ton CPO (Ditjen Perkebunan, 2014). Propinsi Riau merupakan propinsi yang memiliki perkebunan sawit yang paling luas di Indonesia, yaitu seluas 2,3 Ha dengan produksi 7,04 juta ton CPO (Ibid, 2014).

Tanaman kelapa sawit mempunyai masa produktif \pm 25 - 30 tahun, setelah itu tanaman tidak 
akan menghasilkan Tandan Buah Segar (TBS) sehingga harus dilakukan peremajaan. Pustekolah (2013) menjelaskan bahwa peremajaan kebun sawit akan dilakukan setiap tahunnya, yaitu sekitar 150.000 Ha dan akan mengalami peningkatan secara terus menerus. Setiap hektar kebun sawit yang diremajakan, akan dilakukan penebangan sekitar 128 batang pohon sawit tua, atau setara dengan 220 $\mathrm{m}^{3} /$ hektar. Dengan demikian, setiap tahun terdapat 81,5 juta $\mathrm{m}^{3}$ batang sawit yang akan menjadi limbah. Limbah batang sawit telah dimanfaatkan sebagai kayu solid maupun papan lapis. Namun, kelemahan dari batang sawit adalah tingginya kadar air dan kandungan pati dalam batang, sehingga produk yang dihasilkan menjadi tidak stabil dan rentan terhadap pertumbuhan mikroorganisme (Pustekolah, 2013).

Penelitian tentang pembuatan pupuk kompos umumnya menggunakan tandan kosong kelapa sawit (TKKS) yang merupakan limbah dari pabrik minyak sawit. Menurut Singh et al. (1990) dalam Sutanto et al. (2005), TKKS mengandung unsur $\mathrm{C}, \mathrm{K}, \mathrm{N}, \mathrm{P}, \mathrm{Mg}$ berurutan sebesar $42,8 \% ; 2,90 \% ; 0,80 \% ; 0,30 \%$ dan unsur B, Cu dan $\mathrm{Zn}$ berurutan sebesar 10 ppm; 23 ppm dan 51 ppm. Selain TKKS yang dihasilkan dari limbah pabrik pengolahan minyak sawit, terdapat beberapa limbah padat dalam jumlah besar yang dihasilkan bukan dari kegiatan pengolahan minyak sawit namun dihasilkan dari kegiatan peremajaan perkebunan sawit seperti batang sawit 74,48 (bobot kering/ha/30 tahun), pelepah 14,47 ton/ha/30 tahun, pangkasan 10,40 ton/ha/tahun, serat buah 1,63 ton/ha, dan cangkang 0,94 ton/ha (Ditjen PPHP, 2006).

Limbah batang sawit mengandung unsur hara yang cukup besar sehingga sangat berpotensi menjadi bahan baku pupuk organik (pupuk kompos). Penelitian terbaru limbah biomassa sawit yang dikompos masih berbahan baku tandan kosong kosong (Siddiquee et al. (2017); Trisakti et al. (2017)). Namun, penelitian tentang pembuatan pupuk kompos dari batang sawit belum dilakukan. Unsur hara yang dikandung oleh limbah batang sawit diantaranya yaitu $\mathrm{N}$; $\mathrm{P} ; \mathrm{K}$; Mg dan Ca masingmasing 3-368,2; 0,1-35,5; 0,8-527,4; 0,2-82,3 dan 0,2-166,4 (kg/ha) (Ditjen PPHP, 2006).

Masalah utama pengomposan limbah batang sawit umumnya adalah tingginya rasio $\mathrm{C} / \mathrm{N}$, karena batang sawit mengandung kadar kayu tinggi. Untuk menurunkan rasio $\mathrm{C} / \mathrm{N}$ pada bahan yang mengandung kadar kayu tinggi diperlukan perlakuan khusus dengan menambahkan kotoran hewan karena mengandung banyak senyawa nitrogen $(\mathrm{N})$ (Isroi, 2008). Pada proses pengomposan juga dilakukan penambahan dekomposer seperti mikroorganisme lokal (MOL). Hal ini bertujuan untuk mempercepat proses pengomposan. Mikroorganime lokal (MOL) adalah mikroorganisme yang dimanfaatkan sebagai starter dalam pembuatan pupuk organik padat maupun pupuk cair. Bahan utama MOL terdiri dari beberapa komponen yaitu karbohidrat, glukosa, dan sumber mikroorganisme. MOL yang digunakan dalam penelitian ini adalah dari bonggol pisang yang memiliki mikrobia pengurai bahan organik antara lain Bacillus sp., Aeromonas sp., dan Aspergillus nigger (Kesumaningwati, 2015). Dengan demikian penelitian ini bertujuan untuk mendapatkan komposisi pupuk kompos yang terbaik berdasarkan hasil analisis dan sesuai dengan standar Peraturan Menter Pertanian Nomor 70/Permentan/SR. 140/10/2011 tentang pupuk organik, pupuk hayati dan Pembenah Tanah.

Menurut Peraturan Menteri Pertanian No. 70/Permentan/SR.140/10/2011, pupuk organik adalah pupuk yang berasal dari tumbuhan mati, kotoran hewan dan/atau bagian hewan dan/atau limbah organik lainnya yang telah melalui proses rekayasa, berbentuk padat atau cair, dapat diperkaya dengan bahan mineral dan/atau mikroba, yang bermanfaat untuk meningkatkan kandungan hara dan bahan organik tanah serta memperbaiki sifat fisik, kimia dan biologi tanah. Proses pengomposan merupakan rekayasa dalam menghasilkan pupuk organik. Pengomposan merupakan proses perombakan (dekomposisi) dan stabilisasi bahan organik oleh mikroorganisme dalam keadaan lingkungan terkendali. Proses pengomposan akan memperkecil rasio Carbon/ Nitrogen $(\mathrm{C} / \mathrm{N})$ dari bahan baku sehingga sama atau mendekati rasio $\mathrm{C} / \mathrm{N}$ tanah, yaitu di bawah 20. Namun, bahan baku pada umumnya mempunyai rasio $\mathrm{C} / \mathrm{N}$ tinggi, misalnya rasio $\mathrm{C} / \mathrm{N}$ jerami padi 50-70, dedaunan $>50$, sedangkan $\mathrm{C} / \mathrm{N}$ kayu tua mencapai 400 (Indriani, 2005).

Pada proses pengomposan terjadi berbagai perubahan, yaitu karbohidrat, selulosa, hemiselulosa, lemak dan lilin menjadi $\mathrm{CO} 2$ dan air, protein menjadi amonia, CO2 dan air. Adapun senyawa organik terurai menjadi senyawa yang siap diserap oleh akar tanaman (Indriani, 2005). Proses pengomposan dapat berlangsung secara aerobik dan anaerobik. Pada proses aerobik akan dihasilkan $\mathrm{CO}_{2}$, air dan panas, sedang pada proses anaerobik dihasilkan metana, $\mathrm{CO}_{2}$ dan senyawa antara misalnya asam organik. Berbagai faktor yang mempengaruhi proses pengomposan yaitu: $\mathrm{C} / \mathrm{N}$ ratio, ukuran dan komposisi bahan, jumlah mikroba, kelembaban, aerasi, suhu dan keasaman.

Semakin kecil rasio $\mathrm{C} / \mathrm{N}$ bahan baku maka semakin cepat proses pengomposan. Demikian pula semakin kecil ukuran bahan maka akan semakin cepat proses pengomposan karena semakin luas permukaan bahan yang bersinggungan dengan mikroba. Proses pengomposan dari berbagai macam bahan baku akan lebih baik dan lebih cepat daripada dari bahan tunggal dan penambahan kotoran hewan biasanya dapat mempercepat pengomposan (Indriani, 2005).

Pada proses pengomposan bekerja berbagai macam mikroba, semakin banyak mikroba maka akan semakin cepat pengomposan berlangsung. Salah satu alternatif untuk memperoleh koloni mikroba dalam jumlah yang besar adalah dengan menggunakan MOL (Mikroorganisme Lokal). MOL dapat diproduksi melalui teknologi yang sederhana dengan memanfaatkan sumber daya alam di sekitar kita. Beberapa jenis MOL yang dapat digunakan sebagai 
pengganti bioaktivator komersil yaiu MOL bonggol pisang, MOL rebung, MOL limbah rumah tangga, dan berbagai jenis MOL dari limbah bahan organik lainnya. MOL bonggol pisang merupakan MOL yang memiliki kandungan unsur hara dan kekayaan mikroba yang sangat tinggi. Selain itu juga mengandung hormon tumbuh yang dapat meningkatkan unsur hara pada pupuk organik. Oleh karena itu, keberhasilan pembuatan pupuk kompos dapat dipengaruhi oleh penambahan MOL bonggol pisang sebagai decomposer. Mikro organisme lokal yang terdapat pada bonggol inilah yang berfungsi sebagai dekomposer untuk menguraikan bahan organik pada pembuatan pupuk organik. MOL berfungsi sebagai decomposer pengurai bahan organik pada pembuatan pupuk organik. MOL bonggol pisang selain berfungsi sebagai bahan organik, juga mengandung unsur hara NPK serta hormon auksin, giberelin dan sitokinin yang baik untuk pertumbuhan tanaman (Salma dan Purnomo, 2015).

Penambahan POME atau kotoran kambing sebagai bahan tambahan berfungsi sebagai sumber nutrisi bagi mikroorganisme. Selanjutnya penambahan sekam padi berfungsi sebagai media lebur tanah dan mencegah terjadinya kepadatan tanah sehingga meningkatkan sistem aerasi/pertukaran udara zona akar tanaman. Sekam padi juga berfungsi sebagai pelengkap sumber organik pada kompos batang sawit. Pada penambahan abu boiler berfungsi menaikkan sifat keasaman pada pupuk yang pada awalnya asam kemudian dinetralisir menjadi basa dengan bantuan mikroorganisme dan meningkatkan kandungan hara K.

Pada proses pengompasan harus dilakukan pengaturan kelembaban, aerasi dan temperature bahan. Hal ini berkaitan dengan kebutuhan hidup mikroba yang akan mendegradasi bahan baku kompos menjadi pupuk kompos. Umumnya mikroba dapat bekerja secara optimal pada kelembaban $\pm 60 \%$. Kelembaban yang tidak sesuai akan menyebabkan tidak berkembangnya atau bahkan matinya mikroba. Proses aerasi dapat dilakukan dengan pembalikan, misalnya sekali dalam seminggu tergantung kondisi pengomposan, aerobik atau anaerobik. Suhu pengomposan optimal $30-50^{\circ} \mathrm{C}$ dan selama proses dekomposisi suhu dijaga agar tetap $60^{\circ} \mathrm{C}$ selama 3 minggu. Pada suhu tersebut bakteri akan bekerja secara optimal, bakteri patogen dan biji gulma akan mati, dan terjadi penurunan rasio $\mathrm{C} / \mathrm{N}$. Apabila suhu terlalu tinggi, mikroba akan mati, sebaliknya bila terlalu rendah mikroba tidak dapat bekerja atau dorman. Keasaman yang baik dalam pengomposan adalah pada $\mathrm{pH}$ 6,5-7,5. Bila keasaman rendah dapat ditambahkan kapur atau abu (Veronika, 2015).

\section{BAHAN DAN METODE}

\section{Tempat dan Waktu}

Penelitian ini dilaksanakan selama enam bulan dimulai pada bulan Juni sampai dengan
Desember 2014 di Mini Plant Program Studi Teknik Pengolahan Sawit.

\section{Bahan dan Alat}

Bahan baku yang digunakan dalam proses pembuatan pupuk organik ini adalah batang sawit, pome dan kotoran kambing, abu boiler, sekam padi, dan MOL bonggol pisang. Bahan yang digunakan untuk membuat mikroorganisme lokal (MOL) adalah urine sapi, air kelapa, gula merah, dan bonggol pisang. Alat yang digunakan dalam pembuatan pupuk organik adalah kapak, parang, cutter mill (peralatan pabrik pengolahan limbah Politeknik Kampar), baskom, ember, timbangan, sekop dan terpal dan peralatanperalatan untuk pengujian.

\section{Tahapan Penelitian}

Penelitian dilakukan dua tahap, yaitu tahap pembuatan MOL bonggol pisang, dan tahap pembuatan pupuk kompos. Komposisi pembuatan MOL yang digunakan merujuk pada hasil penelitian (Veronika, 2015) yaitu bonggol pisang: urin sapi: air kelapa: gula merah dengan perbandingan $2: 1: 1: 1 \%$ (b/b). Pada pembuatan MOL bonggol pisang, dilakukan pencincangan bonggol pisang hingga berukuran $2 \times 2$ $\mathrm{cm}$. Gula merah dilarutkan kedalam air kelapa. Kemudian semua bahan termasuk urin sapi dimasukkan ke dalam wadah yang telah berisi bonggol pisang dan diaduk hingga tercampur rata.Wadah kemudian ditutup rapat hingga kedap udara dan dilakukan fermentasi selama 2 minggu dan dilakukan pengadukan sekali dalam sehari.

Tahap selanjutnya adalah pembuatan pupuk organik/kompos melalui proses pengomposan merujuk pada penelitian (Veronika, 2015). Batang sawit dicacah hingga menyerupai serbuk gergaji menggunakan mesin cutter mill. POME yang digunakan, dipisahkan antara air, minyak dan sludge dengan menggunakan Decanter. Kemudian sekam padi dihaluskan dengan menggunakan alat roller mill hingga menjadi serbuk. Kemudian seluruh bahan termasuk abu boiler ditimbang sesuai dengan variabel yang digunakan pada penelitian ini.Seluruh bahan baku yang telah ditimbang, kemudian ditumpuk dan diaduk menjadi satu dan dicampur dengan MOL yang telah disediakan untuk selanjutnya dikomposting selama satu bulan. Selama proses composting dilakukan pembalikan tumpukan kompos sekali seminggu. Pembalikan tumpukan kompos ini harus dilakukan secara merata untuk megatur kelembaban, aerasi dan temperatur pengomposan. Selanjutnya setelah 1 bulan dilakukan pengambilan sampel untuk mengetahui niai kadar air. Nilai kadar air pupuk hasil pengomposan ini menjadi salah satu indikator bahwa proses pengomposan telah sempurna terjadi. Setelah proses pengomposan selesai, maka dilakukan analisis kadar air, total NPK, kandungan $\mathrm{C}$-organik, rasio $\mathrm{C} / \mathrm{N}$, dan $\mathrm{pH}$ yang akan dibandingkan dengan standar mutu pupuk organik yang ditetapkan oleh Menteri Pertanian No.70/permentan/SR.140/10/2011. 


\section{Rancangan Penelitian}

Penelitian ini menggunakan model rancangan acak lengkap (RAL) dengan 2 faktor yaitu komposisi batang sawit dengan lima taraf yaitu 3,6,9,12,15 b/b (\%) dan jenis bahan tambahan dengan dua taraf yaitu POME dan kotoran kambing. Adapun variabel perbandingan komposisi adalah batang sawit : POME dan atau kotoran kambing: sekam padi: abu boiler untuk masing-masing perlakuan adalah $3: 10: 2: 1, \quad 6: 10: 2: 1, \quad 9: 10: 2: 1, \quad 12: 10: 2: 1, \quad$ dan 15:10:2:1

\section{HASIL DAN PEMBAHASAN}

\section{Karakteristik Pupuk Kompos Batang Sawit}

Penelitian pembuatan pupuk kompos berbahan baku batang sawit ini menggunakan beberapa bahan tambahan lainnya seperti POME, kotoran kambing, abu boiler, sekam padi dan MOL bonggol pisang. Sebelum dilakukan pengomposan, seluruh bahan baku dicacah untuk memperkecil ukuran sehingga mempercepat proses penguraian oleh mikroorganisme. Ukuran yang semakin kecil akan memperluas permukaan bahan yang kontak langsung dengan mikroorganisme. Pada penelitian ini digunakan MOL bonggol pisang sebagai sumber mikroorganisme yang akan mengubah bahan baku menjadi pupuk organik (pupuk kompos). Hasil analisis MOL bonggol pisang sebagai decomposer ditampilkan pada Tabel 2.

Tabel 2. Hasil analisis MOL bonggol pisang

\begin{tabular}{lc}
\hline \multicolumn{1}{c}{ Parameter } & Nilai (satuan) \\
\hline $\mathrm{pH}$ & 5,6 \\
$\mathrm{C}$ organnik & $5,01 \%$ \\
Rasio C/N & 100 \\
NPK & $0,28 \%$ \\
Total mikrobia & $3200 \mathrm{cfu} / \mathrm{mL}$ \\
\hline
\end{tabular}

\section{Karakteristik Pupuk Kompos Batang Sawit}

Berdasarkan analisis terhadap beberapa parameter uji sesuai dengan standar Permentan No. 70/Permentan/SR.140/10/2011 diperoleh informasi yang akan menentukan kualitas pupuk kompos yang telah dihasilkan. Parameter uji tersebut meliputi nilai kadar air, total NPK, kandungan C-organik, rasio $\mathrm{C} / \mathrm{N}$, dan $\mathrm{pH}$.

\section{Kadar Air}

Kadar air memiliki pengaruh yang besar untuk mempercepat proses penguraian atau dekomposisi bahan-bahan organik yang digunakan dalam pembuatan kompos. Berdasarkan hasil penelitian kadar air yang terkandung di dalam bahan memberikan pengaruh terhadap aktivitas mikroba pengurai. Umumnya mikroba pengurai membutuhkan kelembaban tinggi untuk dapat tumbuh optimum.

Proses dekomposisi bahan kompos diduga telah tercapai apabila kadar air yang terkandung di dalam kompos kurang dari $25 \%$ sesuai dengan standar No.70/permentan/SR.140/10/2011 yaitu $15-25 \%$. B erdasarkan analisis pupuk kompos yang dihasilkan maka yang berada di luar standar adalah perlakuan 2, 3 dan 4 dengan nilai di bawah 15\% (Gambar 1). Jika kadar air dari proses pengomposan rendah akan mengakibatkan proses biologis berjalan lambat dan mengakibatkan berkurangnya populasi mikroorganisme pengurai karena terbatasnya habitat yang ada. Namun, kadar air yang terlalu tinggi akan menyebabkan ruang antar partikel menjadi penuh oleh air, sehingga mencegah gerakan udara dalam tumpukan kompos dan menghambat aktivitas mikroorganisme, sehingga menimbulkan bau (Veronika, 2015).

Selain itu kadar air yang berlebihan juga menurunkan suhu dalam tumpukan sampah organik. Oleh karena itu, setiap satu minggu dilakukan pembalikan karena dengan adanya pembalikan pada tumpukan kompos. Pembalikan memberikan sirkulasi udara segar yang diperlukan untuk mengurangi kadar air dan menghindari kondisi anaerob. Menurut Isroi (2008) kondisi anaerob tidak diinginkan selama proses pengomposan karena akan dihasilkan bau yang tidak sedap. Proses anerob akan menghasilkan senyawasenyawa yang berbau tidak sedap, seperti asam-asam organik, amonia dan $\mathrm{H}_{2} \mathrm{~S}$. Penurunan kadar air ini menunjukkan bahwa kompos mulai masuk pada fase pematangan. Penurunan kadar air pada kompos selama proses pengomposan disebabkan karena penguapan air menjadi gas akibat adanya aktivitas mikroorganisme.

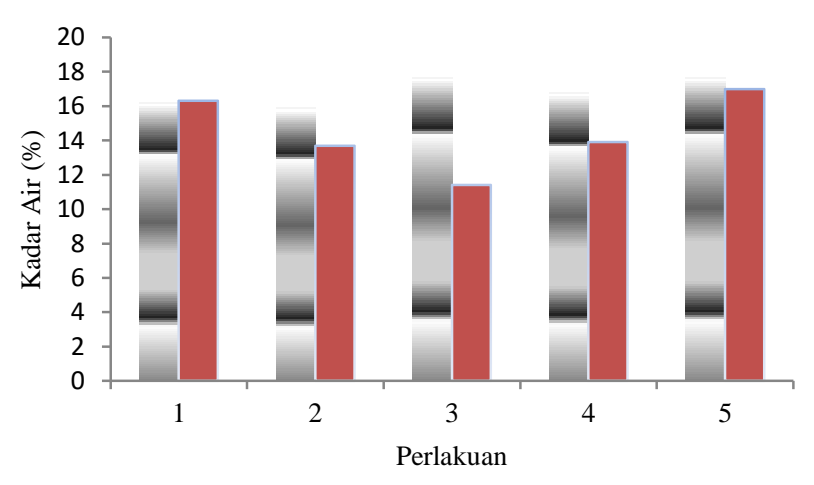

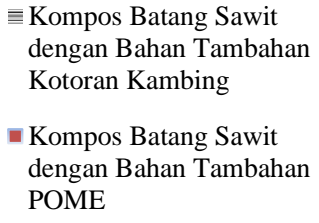

POME

Gambar 1. Kadar air pada pupuk kompos yang dihasilkan 


\section{Total NPK}

Unsur hara makro yang dibutuhkan tanaman adalah unsur N, P, K Mg, Ca, dan S (Jovita 2018). Berdasarkan Peraturan Menteri Pertanian No.70/permentan/SR.140/10/2011, standar total NPK yang ditetapkan adalah minimal $4 \%$.

Berdasarkan hasil penelitian, secara keseluruhan produk pupuk kompos berbahan utama batang sawit ini telah sesuai dengan standar yang telah ditetapkan. Nilai Total NPK tertinggi terdapat pada ke 4 perlakuan yang diberikan tambahan POME yaitu sebesar 8,18\% (Gambar 2). Unsur N berperan untuk membantu pertumbuhan vegetatif pada tumbuhan, khususnya bagian daun. Unsur $\mathrm{P}$ bagi tumbuhan berperan membantu mempercepat perkembangan akar dan perkecambahan, dapat meningkatkan efisiensi penggunaan air, meningkatkan daya tahan terhadap penyakit dan merangsang pembungaan dan pembuahan sehingga meningkatkan kualitas hasil panen (Foth (1997) dalam Jovita (2018). Unsur K berperan dalam proses metabolisme tanaman seperti mengaktifkan kerja enzim, membuka dan menutup stomata (dalam pengaturan penguapan dan pernafasan), transportasi hasil-hasil fotosintesis (karbohidrat), meningkatkan daya tahan tanaman terhadap kekeringan dan penyakit tanaman (Hakim et al. (1986) dalam Jovita (2018)).

Terpenuhinya nilai total NPK karena tingginya kandungan NPK pada bahan baku utama, yaitu batang sawit dimana bobot N (368,2 kg/ha tanaman), P (35,5 kg/ha tanaman) dan $\mathrm{K}(527,4 \mathrm{~kg} / \mathrm{ha}$ tanaman) (Ditjen PPHP, 2006). Dengan terpenuhinya standar minimal total NPK ini, maka pupuk kompos dari batang sawit ini berfungsi ganda yaitu selain menambah hara di dalam tanah, juga meningkatkan kandungan bahan organik tanah yang sangat diperlukan bagi perbaikan sifat fisik tanah. Dengan meningkatnya bahan organik tanah maka struktur tanah semakin baik dan kemampuan menahan air akan bertambah baik. Perbaikan sifat fisik tanah tersebut berdampak positif terhadap pertumbuhan akar tanaman dan penyerapan unsur hara (Rozy et al., 2013).

\section{C-Organik}

Kandungan C-organik pada pupuk kompos merupakan indikator terjadinya proses dekomposisi dalam pengomposan dan kematangan kompos. Corganik merupakan karbon yang digunakan sebagai sumber energi bagi mikroorganisme untuk menyusun sel-sel dengan membebaskan $\mathrm{CO}_{2}$ dan bahan lainnya (Mirwan, 2015). Oleh karena itu, keberadaan Corganik dalam tanah akan meningkatkan aktivitas mikroorganisme dan dapat meningkatkan proses dekomposisi tanah dan juga reaksi-reaksi yang memerlukan bantuan mikroorganisme, misalnya pelarutan P, dan fiksasi N (Afandi, 2015). C-Organik pada pupuk kompos yang dihasilkan disajikan pada Gambar 3.

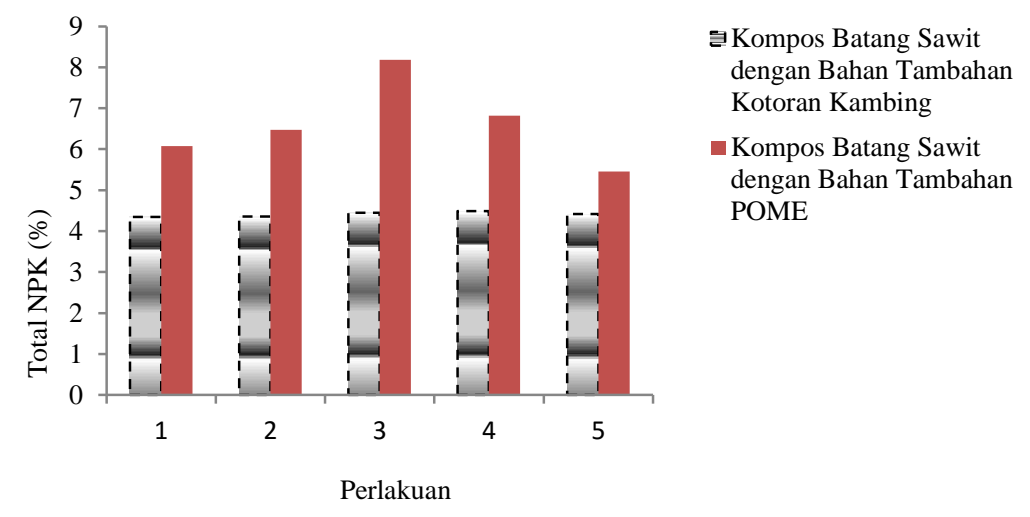

Gambar 2. Total NPK pada pupuk kompos yang dihasilkan

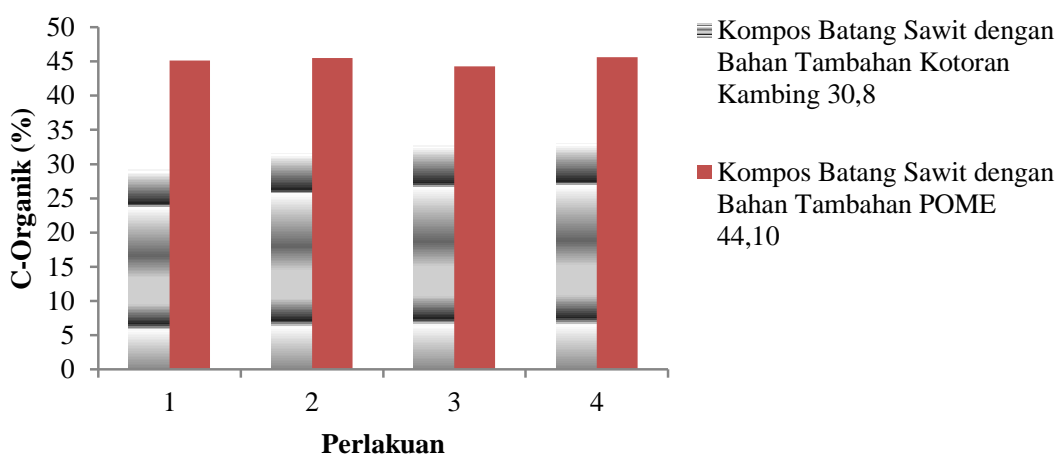

Gambar 3. C-Organik pada pupuk kompos yang dihasilkan 
Kandungan C-organik pada setiap variasi perlakuan penelitian ini telah memenuhi standar yang telah ditetapkan, yaitu minimal 15\%. Kandungan Corganik tertinggi terdapat pada perlakuan 3 dan 5 dengan menggunakan bahan tambahan POME. Penggunaan POME dapat meningkatkan unsur Corganik di dalam kompos sehingga dengan pemberian pupuk kompos ini dapat meningkatkan kandungan Corganik tanah. Apabila C-organik tanah meningkat maka akan mempengaruhi sifat tanah menjadi lebih baik secara fisik, kimia dan biologi.

C-organik berfungsi sebagai penyangga biologis tanah yang mampu menyeimbangkan hara dalam tanah dan menyediakan unsur hara bagi tanaman secara efisien. Jika unsur C-organik dalam tanah rendah, daya sanggah hara juga rendah sehingga pemupukan menjadi tidak efisien.

\section{Rasio C/N}

Nilai rasio $\mathrm{C} / \mathrm{N}$ bahan organik pada pupuk kompos merupakan faktor penting dalam pengomposan yang dibutuhkan mikroorganisme sebagai sumber nutrisi untuk pembentukan sel-sel tubuhnya. Semakin besar nilai defisiensi rasio $\mathrm{C} / \mathrm{N}$ akan menyebabkan proses pengomposan menjadi lebih cepat, dan proses pengomposan yang terjadi semakin baik. Adanya penurunan rasio $\mathrm{C} / \mathrm{N}$ dan lamanya waktu pengomposan merupakan parameter keberhasilan proses pengomposan (Ayuningtias, 2009).

Sebagian besar hasil penelitian telah memenuhi standar rasio $\mathrm{C} / \mathrm{N}$ yang telah ditetapkan oleh Permentan No.70/permentan/SR.140/10/2011 yang nilainya berada pada kisaran nilai $15-18 \%$. Perlakuan yang tidak memenuhi standar diperoleh pada perlakuan 2, 3 dan 4 pada penggunaan bahan tambahan POME. Hal ini diduga disebabkan oleh adanya pengaruh nilai $\mathrm{C} / \mathrm{N}$ dari POME. Nilai rasio $\mathrm{C} / \mathrm{N}$ tersebut yang mempengaruhi proses pengomposan. Semakin tinggi rasio $\mathrm{C} / \mathrm{N}$ suatu bahan maka semakin lambat untuk diubah menjadi kompos. Sebaliknya bahan dengan rasio $\mathrm{C} / \mathrm{N}$ yang rendah akan mempercepat proses pengomposan, tetapi apabila nilai rasio $\mathrm{C} / \mathrm{N}$ terlalu rendah maka pengomposan akan menghasilkan produk sampingan yaitu gas amoniak yang berbau busuk (Veronika, 2015).

\section{pH Pupuk Kompos}

Tingkat keasaman atau pH pada pupuk merupakan salah satu faktor kritis bagi pertumbuhan mikroorganisme yang terlibat dalam proses pengomposan. $\mathrm{pH}$ diukur sebagai indikator proses dekomposisi kompos. Pada tahap dekomposisi, akan terbentuk asam-asam organik sehingga menyebabkan $\mathrm{pH}$ turun. Tahap selanjutnya adalah perubahan asam organic akan dimanfaatkan kembali oleh mikroba lain, sehingga pH akan kembali netral dan kompos menjadi matang.

Perubahan $\mathrm{pH}$ kompos berawal dari $\mathrm{pH}$ agak asam karena terbentuknya asam-asam organik sederhana, kemudian $\mathrm{pH}$ meningkat pada inkubasi lebih lanjut akibat terurainya protein dan terjadinya pelepasan ammonia (Supadman, 2008). Derajat keasaman yang terlalu tinggi juga akan menyebabkan unsur nitrogen dalam bahan kompos berubah menjadi ammonia (NH3), sebaliknya dalam keadaan asam rendah akan menyebabkan sebagian mikroorganise mati. Secara keseluruhan $\mathrm{pH}$ pupuk kompos telah memenuhi standar yang telah ditetapkan, yaitu $4-9$, kecuali pada variabel 5 pada penggunaan bahan tambahan POME yang berada pada $\mathrm{pH} 9,06$.

Berdasarkan hasil analisis, maka komposisi pupuk kompos terbaik diperoleh pada perlakuan dengan perbandingan batang sawit : POME: sekam padi : abu boiler $=3: 10: 2: 1$. Dengan hasil analisis kadar air $16,30 \%$, total NPK 6,08\%, kandungan C-organik $44,10 \%$, rasio $\mathrm{C} / \mathrm{N}=16,30$ dan $\mathrm{pH} 8,16$.

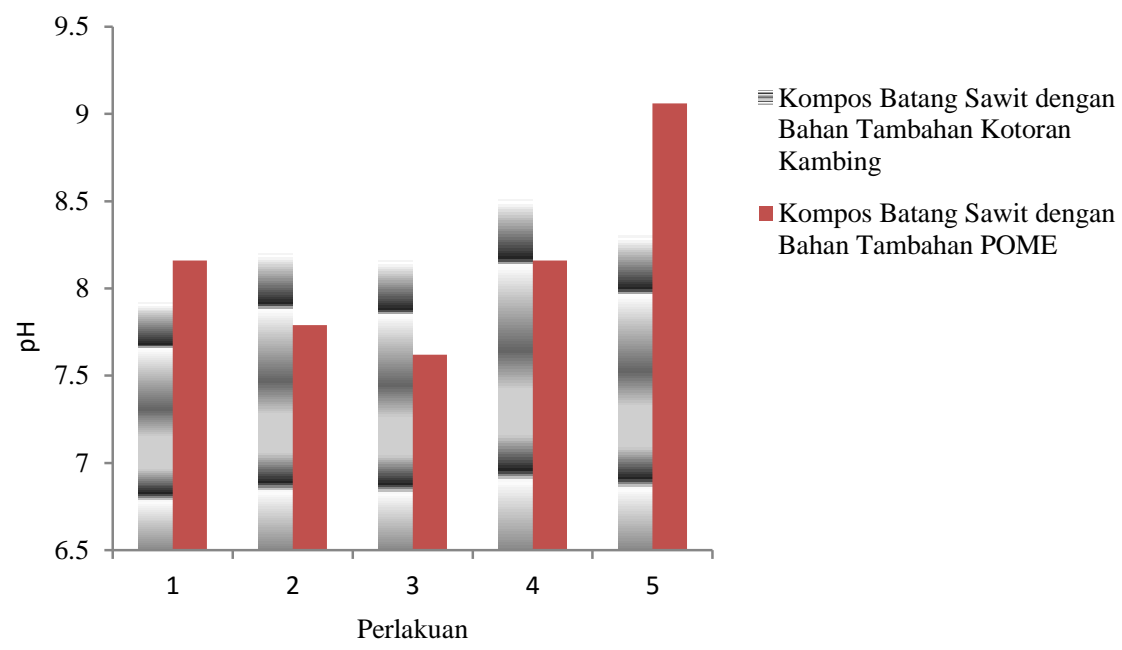

Gambar 5. pH pada pupuk kompos yang dihasilkan 


\section{KESIMPULAN DAN SARAN}

Komposisi pupuk kompos terbaik diperoleh pada variasi perlakuan dengan perbandingan batang sawit: POME: sekam padi: abu boiler yaitu 3:10:2:1 dengan karakteristik pupuk kompos sebagai berikut: kadar air $16,30 \%$, total NPK 6,08\%, kandungan Corganik 44,10\%, rasio $\mathrm{C} / \mathrm{N} 16,30$ dan $\mathrm{pH} 8,16$. Hasil analisis ini telah memenuhi standar pupuk organik yaitu Permentan No. 70/Permentan/SR. 140/10/2011.

\section{DAFTAR PUSTAKA}

Afandi FN, Siswanto B, dan Nuraini Y. 2015. Pengaruh pemberian berbagai jenis bahan organik terhadap sifat kimia tanah pada pertumbuhan dan produksi tanaman ubi jalar du entisol ngrangkah pawon, Kediri. Jurnal Tanah dan Sumber Daya Lahan. 2 (2): $237-244$.

Ayuningtias DN. 2009. Pengaruh ketersediaan oksigen dan sistem aerasi terhadap laju proses pengomposan dan kualitas kompos berbahan baku limbah pencucian biji kakao terfermentasi, serasah daun, dan kotoran sapi. [Skripsi]. Bogor: Institut Pertanian Bogor.

Ditjen PPHP. 2006. Pedoman Pengelolaan Limbah Industri Kelapa Sawit. Subdit Pengelolaan Lingkungan. Direktorat Pengolahan Hasil Pertanian. Ditjen PPHP. Jakarta: Departemen Pertanian.

Ditjen Perkebunan. 2014. Statistik Perkebunan Indonesia Komoditas Kelapa Sawit 2013 2015. Jakarta: Direktorat Jenderal Perkebunan.

Febrisiantosa A, Rosyida VT, dan Suharwadji. 2009. Pengaruh pemberian sludge cair terhadap hasil tanaman jagung (Zea mays). Proceedings of 6th Basic Science National Seminar, Jurusan Fisika, FMIPA, Universitas Brawijaya. Malang: 21 Februari 2009, 75-77.

Foth HD dan Ellis BG. 1997. Soil Fertility. CRC Press, Inc. Florida. Pp. 55-57.

Isroi. 2009. Pupuk Organik Granul :Sebuah Petunjuk Praktis. Yogyakarta: CV Andi Offset.

Indriani. 2004. Membuat Kompos secara Kilat. Jakarta: Penebar Swadaya.

Jovita D. 2018. Analisis unsur makro (K,Ca, Mg) Mikro (Fe, Zn, $\mathrm{Cu}$ ) pada lahan pertanian dengan metode inductively coupled plasma optical Emission Spectrofotometry (ICPOES). [Skripsi]. Bandar Lampung: Universitas Lampung.

Kesumaningwati R. 2015. Penggunaan bonggol pisang (Musa paradisiaca) sebagai dekomposer untuk pengomposan tandan kosong kelapa sawit. Jurnal Ziraa'ah. 40(1): 40-45.

Pahan I. 2010. Panduan Lengkap Kelapa Sawit: Manajemen Agribisnis dari Hulu hingga Hilir. Jakarta: Penebar Swadaya.

Pustekolah. 2013. Siaran Pers; Kayu Sawit: Mengubah Sampah Menjadi Rupiah.[Online],http://www.pustekolah.org /index.php/detail/321/SIARAN-PERSKayu-Sawit-Mengubah-Sampah-MenjadiRupiah\#.UZ2ZabXwmSo. [5 Mei 2016].

Mirwan M. 2015. Optimasi pengomposan sampah kebun dengan variasi aerasi dan penambahan kotoran sapi sebagai bioaktivator. Jurnal Ilmiah Teknik Lingkungan. 4(1):61-66.

Purnamayani R. 2012. Kajian Pemanfaatan Kompos Tandan Kosong Kelapa Sawit sebagai Substitusi Pupuk Kalium Mendukung Pertanian Sayuran Organik di Provinsi Jambi. Jambi: Balai Pengkajian Teknologi Pertanian (BPTP).

Roidah IS. 2013. Manfaat penggunaan pupuk organik untuk kesuburan tanah. Jurnal Universitas Tulungagung Bonorowo. 1(1): $30-42$.

Rozy F, Rosmawaty T, dan Fatrrahman. 2013. Pemberian pupuk NPK mutiara 16:16:16 dan kompos tandan kosong kelapa sawit pada tanaman terung (Solanum melongena L). Jurnal RAT. 1(2): 228-239.

Sahwan FL, Wahyono S, dan Suryanto F. 2011. Evaluasi proses produksi pupuk organik granul (POG) yang diperkaya dengan mikroba fungsional. Jurnal Teknik Lingkungan. 12(1): 7-16

Salma S dan Purnomo J. 2015. Pembuatan MOL dari bahan bakulokal. Bogor:Agro Inovasi.

Siddiquee S, Shafawati SN, dan Naher L. 2017. Effective composting of empty fruit bunch using potential trichodrema strains. Journal Biotechnology Reports. 13: 1-7.

Sirappa MP dan Wahid. 2012. Kajian tiga jenis pupuk organik terhadap pertumbuhan dan hasil padi rawa di desa debowae, kecamatan waeapo, kabupaten Buru. Jurnal Budidaya Pertanian. 8(2): 96-100.

Suherman I, Awaluddin A, dan Itnawati. 2014. Analisis kualitas kompos dari campuran tandan kosong kelapa sawit dengan kotoran ayam menggunakan limbah cair pabrik kelapa sawit dan EM4. JOM FMIPA. 1(2).

Supadman AAN dan Arthagama DM. 2008. Uji formulasi kualitas pupuk kompos yang bersumber dari sampah organik dengan penambahan limbah ternak ayam, sapi, babi dan tanaman pahitan. Jurnal Bumi Lestari. 8(2): 113-121.

Suriawiria U. 2002. Pupuk Organik Kompos dari Sampah. Bandung: Humaniora. 
Sutanto A, Prasetyo AE, Fahroidayanti, Lubis AF, Dongoran AP. 2005. Viabilitas bioaktivator jamur trichoderma koningii pada media tandan kosong kelapa sawit. Jurnal Penelitian Tandan Kelapa Sawit. 13(1):25-33.

Trisakti B, Mhardela P, Husaini T, Irfan, Daimon H. 2017. Production of oil palm empty fruit bunch compost for ornamental plant cultivation. IOP Conference Series: Material Science and Engeneering. 309. (1)
Veronika N dan Walabi. 2015. Pengaruh penambahan dolomit dan abu boiler sebagai bahan perekat terhadap kualitas pupuk organik granul di unit pengolahan limbah politeknik Kampar. Jurnal Sawit Indonesia. 5(2): 17-23.

Yulianto A. 2009. Pembuatan kompos dari tandan kosong kelapa sawit. Infosawit Juni .49-51. 